\title{
Twentieth Century Music and the Question of Modernity
}

Eduardo De La Fuente

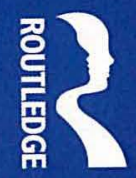




\section{Twentieth Century Music and the Question of Modernity}




\section{Routledge Advances in Sociology}

For a full list of title in this series, please visit unw.routledge.com

16. Love, Heterosexuality and

Society

Paul Johnson

17. Agricultural Governance

Globalization and the New Politics of

Regulation

Edited by Vaughan Higgins and

Geoffrey Lawrence

18. Challenging Hegemonic

Masculinity

Richard Howson

19. Social Isolation in Modern

Society

Roelof Hortulanus, Anja Machielse

and Ludwien Meeuwesen

20. Weber and the Persistence of

Religion

Social Theory, Capitalism and the

Sublime

Joseph W. H. Lough

21. Globalization, Uncertainty and Late Careers in Society

Edited by Hans-Peter Blossfeld,

Sandra Buchholz and Dirk Hofäcker

22. Bourdieu's Politics

Problems and Possibilities

Jeremy F. Lane

23. Media Bias in Reporting Social

Research?

The Case of Reviewing

Ethnic Inequalities in Education

Martyn Hammersley
24. A General Theory of Emotions and Social Life

Warren D. TenHouten

25. Sociology, Religion and Grace Arpad Szakolczai

26. Youth Cultures

Scenes, Subcultures and Tribes

Edited by Paul Hodkinson and

Wolfgang Deicke

27. The Obituary as Collective

Memory

Bridget Fowler

\section{Tocqueville's Virus}

Utopia and Dystopia in Western Social and Political Thought

Mark Featherstone

29. Jewish Eating and Identity

Through the Ages

David Kraemer

30. The Institutionalization of Social Welfare

A Study of Medicalizing Management Mikael Holmqvist

31. The Role of Religion in Modern Societies

Edited by Detlef Pollack and Daniel V. A. Olson

32. Sex Research and Sex Therapy A Sociological Analysis of Masters and Johnson

Ross Morrow 
33. A Crisis of Waste?

Understanding the Rubbish Society

Martin O'Brien

34. Globalization and

Transformations of Local

Socioeconomic Practices

Edited by Ulrike Schuerkens

35. The Culture of Welfare Markets

The International Recasting of Pension and Care Systems

Ingo Bode

36. Cohabitation, Family and

Society

Tiziana Nazio

37. Latin America and Contemporary Modernity

A Sociological Interpretation

José Maurízio Domingues

38. Exploring the Networked

Worlds of Popular Music

Milieu Cultures

Peter Webb

39. The Cultural Significance of the Child Star

Jane O'Connor

40. European Integration as an

Elite Process

The Failure of a Dream?

Max Haller

41. Queer Political Performance and Protest

Benjamin Shepard

42. Cosmopolitan Spaces

Europe, Globalization, Theory

Chris Rumford

43. Contexts of Social Capital

Social Networks in Communities, Markets and Organizations

Edited by Ray-May Hsung, Nan Lin, and Ronald Breiger
44. Feminism, Domesticity and Popular Culture

Edited by Stacy Gillis and Joanne Hollows

45. Changing Relationships

Edited by Malcolm Brynin and John

Ermisch

46. Formal and Informal Work

The Hidden Work Regime in Europe

Edited by Birgit Pfau-Effinger, Lluis

Flaquer, \& Per H. Jensen

47. Interpreting Human Rights

Social Science Perspectives

Edited by Rhiannon Morgan and

Bryan S. Turner

48. Club Cultures

Boundaries, Identities and Otherness

Silvia Rief

49. Eastern European Immigrant

Families

Mihaela Robila

50. People and Societies

Rom Harré and Designing the Social

Sciences

Luk van Langenhove

51. Legislating Creativity

The Intersections of Art and Politics

Dustin Kidd

52. Youth in Contemporary

Europe

Edited by Jeremy Leaman and

Martha Wörsching

53. Globalization and

Transformations of Social Inequality

Edited by Ulrike Schuerkens

54. Twentieth Century Music and the Question of Modernity

Eduardo De La Fuente 



\title{
Twentieth Century Music and the Question of Modernity
}

\section{Eduardo De La Fuente}

\author{
हु్ㄱ Routledge \\ Taylor \& Francis Group \\ NEW YORK AND LONDON
}


First published 2011

by Routledge

711 Third Avenue, New York, NY 10017

Simultaneously published in the UK

by Routledge

2 Park Square, Milton Park, Abingdon, Oxon OX14 4RN

Routledge is an imprint of the Taylor \& Francis Group, an informa business

First issued in paperback 2012

(C) 2011 Taylor \& Francis

The right of Eduardo De La Fuente to be identified as author of this work has been asserted by him in accordance with sections 77 and 78 of the Copyright, Designs and Patents Act 1988.

Typeset in Sabon by Taylor \& Francis Books

All rights reserved. No part of this book may be reprinted or reproduced or utilised in any form or by any electronic, mechanical, or other means, now known or hereafter invented, including photocopying and recording, or in any information storage or retrieval system, without permission in writing from the publishers.

Trademark Notice: Product or corporate names may be trademarks or registered trademarks, and are used only for identification and explanation without intent to infringe.

Library of Congress Cataloging in Publication Data

Fuente, Eduardo De La.

Twentieth century music and the question of modernity / by Eduardo de la Fuente.

p. cm. - (Routledge advances in sociology; 54)

Includes bibliographical references and index.

1. Modernism (Music) 2. Music-20th century-History and criticism.

3. Music-20th century-Philosophy and aesthetics. 4. Music-20th century-Social aspects. I. Title.

ML197.F86 2010

780.9'04-dc22

ISBN 13: 978-0-415-96208-7 (hbk)

ISBN 13: 978-0-203-84547-9 (ebk)

ISBN 13: 978-0-415-81143-9(pbk) 


\section{Contents}

Acknowledgments viii

$\begin{array}{ll}\text { Introduction } & 1\end{array}$

1 Modernity, Modernism and Music 16

2 Myth and Narrative in Twentieth Century Musical Culture 31

3 The Structure of Musical Revolutions 40

4 Music in Max Weber's Sociology of Modernity 53

5 Modernity in Theodor Adorno's Philosophy of Modern Music 67

6 Music in Modern Theories of Communication $\quad 80$

7 Arnold Schoenberg: The Composer as Prophet 91

8 Igor Stravinsky: The Composer as Priest 103

9 Pierre Boulez: The Composer as Ascetic 115

10 John Cage: The Composer as Mystic 126

11 From Avant-Gardism to Post-Modernism 138

12 Musical Re-enchantment? 154

$\begin{array}{ll}\text { Bibliography } & 168\end{array}$

Index 181 


\section{Acknowledgments}

This project has been in the pipeline for a great number of years and therefore has benefited from the input of a long list of people.

I would like to thank Tony Bennett for supervising a much earlier incarnation of this study as a $\mathrm{PhD}$ thesis at Griffith University, under the title 'Music, Modernity and Social Theory'. The author put the 'music and modernity' project to one side for a number of years until it was given a new lease of life during a period spent as a Faculty Fellow at the Yale Center for Cultural Sociology, in April-June of 2005. In addition to providing a desk in the lovely Queen Anne Revival Mansion that houses the Center for Cultural Sociology, and access to one of the great research libraries, Jeff Alexander, Phil Smith and Ron Eyerman offered a congenial intellectual environment for discovering afresh the possibilities present in a cultural sociology. Phil Smith also offered the perceptive advice that the project sounded like a 'Routledge kind of book' and I am pleased the publisher agreed with him. It was during my period at Yale that I was also able to reacquaint myself with those wonderful Exeter sociologists Bob Witkin and Tia DeNora, who also happened to be passing through New Haven at the time. Their work is a constant source of inspiration; as are the writings of Bernice Martin, a pioneer in the field of the sociology of avant-garde cultures. The latter I only know through her publications but, as the contents of this book reveal, her study A Sociology of Contemporary Cultural Change has been a constant companion during the writing of Twentieth Century Music and the Question of Modernity. It was Gary Easthope, a colleague during my years at the University of Tasmania, who decided to bequeath his copy of Martin's book to a young cultural sociologist then struggling to work out how to write meaningfully about the topic of the arts and cultural change. Martin's work, like the visit to Yale, turned out to be just the tonic I was looking for.

During the writing phase, I was fortunate to have conversations about music and modernity with various other old and new colleagues - John Lechte, John Potts, and Alison Leitch at Macquarie University; and Agnes Heller, Philip Flavin, Peter Murphy, and David Roberts at Monash University. The latter two have an uncanny capacity to preempt where I will head next in my own thinking. I still find it difficult to believe that Chapters 7 and 10 
were anticipated by a conversation the three of us had over lunch in a Carlton hotel in Melbourne, in December of 1999. Peter Murphy also commented on drafts of chapters and I thank him for his editing abilities. I have also been fortunate, during the last three years, to supervise some very talented postgraduate and honors students. I would like to especially thank Michael Walsh and Lawson Fletcher for letting me use them as sounding boards. 



\section{Introduction}

The conductor Sir Simon Rattle's television series about twentieth century art music, and accompanying book (Hall, 1996), has the intriguing title of Leaving Home. The underlying metaphor is explained thus: 'It has been a century of emigration and exile, both voluntary and forced. But "leaving home" is also the dominant metaphor for a time in which all the certainties, social, political and artistic have migrated' (Hall, 1996: 1). The author admits that 'Beginnings can be deceptive' and the twentieth century 'began in a state of relative calm' (Hall, 1996: 1). After all, the era just before and immediately after the beginning of the century was known as the 'Belle Epoque' and the artistic 'culture was still bourgeois, the musical style Romantic' (Hall, 1996: 1). Yet underneath the surface lay a certain uncertainty concerning the effects of new scientific and technological developments (i.e., the motor car, airplane, telephone, cinema, gramophone, X-ray, etc.). Additionally, the new physics undermined 'Newton's theory that the world was stable and mechanically ordered'; while the birth of psychoanalysis led to the view that the 'irrational nature of the unconscious might ... be as important in human behavior as the conscious mind' (Hall, 1996: 2).

However, why music and 'leaving home'? Music provides an ideal metaphor for this process because, in the first decade of the century, there was a significant retreat from the principle of tonality and regular pulse. It was the 'wish to explore worlds lying outside normal experience' that led to the abandonment of tonality and to an 'unprecedented importance to rhythm' (Hall, 1996: 3). Around 1900, composers started - essentially for the first time - to seriously question the humanistic and rationalist cosmology that had prevailed since the Renaissance. In the tonal system, human beings were still 'in harmony with themselves and the world, while at the same time being expressive and dynamically purposeful' (Hall, 1996: 3). Whether we are speaking of Arnold Schoenberg's 1909 melodrama Erwartung, which attempts to capture the inner turmoil of a 'woman searching for her lover,' or Igor Stravinsky's re-creation of a 'barbaric, pagan world' in the 1913 ballet score for the Rite of Spring, the tonal system 'proved unsuitable for those who wanted to look at human experience from another perspective' (Hall, 1996: 3). 


\section{Twentieth Century Music}

But, in the case of music, the metaphor of 'leaving home' has an added implication. It also signifies that musical form had itself abandoned the notion of a 'home' or tonic key:

The tonal system, which Schoenberg abandoned before the First World War, is based on the idea that a piece of music should be like going on a journey, in which you know full where you will end up - namely, back home ... 'home' is the 'tonic' triad of the key that the composer has selected for the piece. Returning to the home key and ultimately finding rest on its tonic chord gives music written in the tonal system, its sense of direction and purpose ... Just as the point where all the certainties and empires and old social order were beginning to crumble ... so music was leaving home, abandoning tonality, seemingly forever.

(Hall, 1996: 25)

One has to be careful in drawing direct homologies between music and social life. As Theodor Adorno (1976: 203-4) correctly observes, 'Society is not, as a hardened dialectical-materialist doctrine pummels into its followers, directly, tangibly and, in the jargon of that doctrine, "realistically" continued in its works of art.' Any sociological theory that 'ignores this remains ... sober, in terms of musical sociology' and leaves that sociology open to 'decretive fantasizing' (Adorno, 1976: 204).

However, there is something inherently interesting for the social theorist of modernity in the notion that the shifts in musical language, of the early part of the twentieth century, were akin to 'leaving home.' The notion of 'leaving home' can be seen as an analogy; but it can also be as a narrative construction. In this respect, musicians are in the same boat as social theorists - even though the chosen medium of the former is sound rather than theoretical concepts. Like the social theorist, the modern musician has had to construct a narrative regarding the 'modern' and what the present, past and future means to their art.

There is a growing recognition that all frameworks for imagining modernity are stories in and of themselves. Jeffrey Alexander $(2003: 193 ; 199)$ makes the dramatic claim that 'really broad intellectuals' are like prophets and priests, and that the task of the intellectual is to 'interpret the world' and that to do so in a 'meaningful, reassuring, or inspiring manner means that intellectuals must make distinctions.' For intellectuals, defining the meaning of their 'time' means identifying a past 'that preceded the present' and also offering their audiences 'a compelling account of why it was superseded' (Alexander, 2003: 199). Similarly, Peter Osborne (1995: 16) writes that "the role of so-called "theories of modernity" ... [is] to provide content to fill the form of the modern, to give it something more than an abstract temporal determinacy.' He also proposes that, as a 'periodizing concept,' modernity registers a 'break' that establishes the 'differential character of its own time and that which precedes it' (Osborne, 1995: 16). 
The aesthetic and cultural consequences of attempts to establish the 'differential character' of modernity, in the realm of music, is one of the major themes of this book.

To return to the metaphor with which we began - the idea that modernity is like 'leaving home' is present, not just in histories of twentieth century music, but also in sociological theoretical accounts. One of the major modern philosophers to write about music, Adorno, could be said to have written about modernity from the vantage point of permanent exile. Indeed, many of his most famous texts were written during his exile in California. In his 1993 Reith Lectures on the subject of intellectuals, Edward Said (1994: 97) proclaims: 'Paradoxical, ironic, mercilessly critical, Adorno was the quintessential intellectual, hating all systems ... with equal distaste.' It is not surprising then that Adorno (1973: 133) sees in modern music 'the surviving message of despair from the shipwrecked.'

However, it wasn't just Adorno who identified with the sociological theme of modernity as a case of 'leaving home.' In The Homeless Mind, Peter Berger, Brigitte Berger and Hans Kellner (1974: 82) propose that with the decline of religion, and the acceleration of secularization-rationalization, 'modern man has suffered from a deepening condition of "bomelessness"' (emphasis in the original). They compare the rootless quality of modern man's 'experience of society' to the sociological process of migration and claim that it has led to 'a metaphysical loss of "home" ... [that] is psychologically hard to bear' (Berger, Berger and Kellner, 1974: 82).

The question is then: what are the existential, aesthetic and even moral consequences of conceiving modernity as a case of 'homelessness'? Again, there are significant overlaps between the musical and sociological narratives regarding the feeling of homelessness that accompanies modernization. The first sociological theorist to place music at the centre of a discussion of modernity was Max Weber, and his profound ambivalence regarding the cultural, consequences of 'disenchantment' are particularly acute in the case of music. Leaving to one side the details of Weber's own sociology of music, which we will examine more fully in Chapter 4, it is worth noting that the musical condition of homelessness (i.e., of music composed without a tonal centre) is exacerbated by rationalization. Crook, Pakulski and Waters (1992) describe the cultural consequences of musical rationalization in this manner:

Weber's sense that music offers the paradigm case of cultural rationalization finds some confirmation in the observation that it is music that becomes the least penetrable of the modernist arts. A non-expert has at least some point of contact with painting, which can be looked at first one way and then another as a visual field. Without quite high-grade skills in music (a capacity to read the score, a basic knowledge of traditional harmony) a twelve-tone composition is simply noise.

(Crook, Pakulski and Waters, 1992: 76n) 


\section{Twentieth Century Music}

However, it would be misleading to simply characterize modern music as hyper-intellectual or rationalism 'gone mad'; twentieth century music also lends weight to the sociological theory that 'control' and 'chaos' are close allies. As we shall see in Chapter 9, the French composer Pierre Boulez has a well-earned reputation as one of the 'ultra-rationalists' of twentieth century music. However, in conversation with the philosopher Michel Foucault, he speaks of musical works that are 'unique events' and essentially contingent in character:

In Classical and Romantic music ... there are schemas which one obeys, The movements of a symphony are defined in their form ... they are distinct from one another, most of the time actually separated by a pause, sometimes tied by a transition that can be spotted. The vocabulary itself is based on 'classified' chord ... Progressively, these reassuring elements have disappeared from 'serious' music ... Musical works have tended to become unique events ... not reducible to any guiding schema, a priori.

(Foucault and Boulez, 1985: 8)

How to make sense then of musical modernity, which seems to be governed by both order and disorder, both rationality and irrationality, and both the will-to-form and the will-to-contingency? One sociological theorist to address the double-sided character of modernity has been Zygmunt Bauman. Bauman (1997: 10) proposes we 'define modernity as the time, or way of life, in which order-making consists of dismantling of the "traditional", inherited and received order; in which "being” means a perpetual new beginning.' For him, modernity is an attempt to classify, organize, tame and 'purify' - in short, it is a 'man-made order' that attempts to limit what is 'out of place' (Bauman, 1997: 6). Bauman's analysis of modernity echoes the account of classificatory schemas in British anthropologist Mary Douglas's (1966) Purity and Danger. Douglas writes of the will-to-purify: 'Dirt offends against order. Eliminating it is not a negative movement, but a positive effort to organize the environment' (cited in Bauman, 1997: 7).

Three additional points can be made about Bauman's conception of modernity. The first is in relation to the 'perpetual new beginning' part of his definition - what we might refer to as the temporal dimension of modernity. Bauman (1997: 10) claims that once the work of 'purifying' or 'ordermaking' becomes a 'conscious/purposeful activity' what happens is that, 'instead of keeping intact the way in which things were,' the activity of 'taking care of order' results in the 'introduction of a new, and by the same token, artificial order.' This consciousness of a 'new beginning,' or a 'momentous change in the status of order coincided with the advent of the modern era' (Bauman, 1997: 10). A second, and related issue, is that Bauman (1997: 11) tends to see every order as producing its own 'disorders; each model of purity has its own dirt that needs to be swept away.' This where 
order and disorder become psychically and practically linked in modernity. Bauman (1997: 11) writes: 'We may go a step further and say that the "order-making" now becomes indistinguishable from announcing ever new "abnormalities", drawing ever new diving lines.' Which brings me to the third and perhaps decisive element in Bauman's theory of modernity namely, the 'fantasies' regarding the need to impose order that modern culture ushers in. As the modern world is 'notoriously unstable and constant solely in its hostility to everything constant, the temptation to arrest the movement, to bring the perceptual change to a halt, to install an order secure against all further challenges, becomes overwhelming and very diffcult to resist' (Bauman, 1997: 11). For Bauman this is the essence of all modern totalitarian ideologies; it also lends modernity an inescapable premodern desire to halt processes of change that are largely beyond one's control.

Does this image of modernity resonate with the culture and practices of twentieth century music? One of the constant themes in that musical culture has been the topic of change and how to cope, classify and order that unprecedented change. A reader opening any book about the history of twentieth century music will be struck by the ritualistic mention of how much musical styles changed in the period 1900-999. To cite one such example:

In the last hundred years, musical styles have changed at an unprecedented rate ... Composers have flown in the face of existing orthodoxies, deliberately flouting established rules, some of them only newly established.

(Ford, 2002: 2)

Notice how, in this quote, the pace of change is itself important. Time matters to modern culture. A common myth, perpetuated by moderns, is that their time is 'unique' or somehow more 'special' or 'challenging' than earlier epochs. As Hans Blumenberg (1993: 457) says, in The Legitimacy of the Modern Age, "[w]e acknowledge as an "epoch" only what has been summoned up by the rhetorical hyperbole that speaks of the "epoch maker".' In the case of twentieth century musical culture, 'epoch-making' duties have fallen upon 'epoch-defining' works, and 'epoch-defining' stylistic innovations, as much as 'epoch-defining' composers. We explore some of these myths and narratives regarding musical change, and the 'structure of musical revolutions,' in Chapters 2 and 3 of this book.

But, where there is order, there is also, explicitly or implicitly, disorder. Thus, as with Bauman's double-sided modernity, unprecedented change produces an unprecedented amount of 'dirt,' as well as attempts - often failed attempts! - to purify, clean and order that dirt. There are many contenders for the category of the 'dirt' within twentieth century musical culture: noise, chance, dissonance, silence, harmony (yes, even harmony became problematic), style, past styles, popular styles, the musical syntax of 
other times and other cultures, and, depending on one's perspective, complexity or simplicity. From this list, the question of 'noise' - what it is and what role it should perform - is particularly illustrative. Modernity is clearly a noise-saturated phenomenon. But the omnipresence of noise heightens the issue of whether some sounds are either random or meaningless. It is also unclear at the outset whether noises increase the sound-pallet of the composer; or present a serious threat to the art of music, as well as the human capacity to deal with one's environment. In short, is noise to be feared or revered, despised or enjoyed?

The case for seeing noise as the dirt of modernity, was advanced by Aldous Huxley, who described the twentieth century as the 'Age of Noise': 'Physical noise, mental noise, and noise of desire - we hold history's record for them ... all the resources of our almost miraculous technology have been thrown into the current assault against silence' (cited in Cox and Warner, 2007: 3). But if noises are everywhere can the composer, as an expert organizer of sound, ignore noise? A decision needs to be made as to whether or not to let noise into music. What if noise is an impurity that actually enriches music? This was the view of American composer Henry Cowell (2007: 23), who wrote in 1929: 'Since the "disease" of noise permeates all music, the only hopeful course is to consider that the noise-germ, like the bacteria of cheese, is a good microbe, which may provide hidden delights to the listener, instead of producing musical oblivion.'

But Cowell presented an even more profound challenge to musical 'ordermaking' - he highlighted that noise is an element of pure musical sounds, much as Schoenberg was to show that dissonance is built into the 'overtones' that are the basis of harmonic music. Cowell (2007: 23) contends that the more we 'search for music based on a pure tone' the more we will confront one 'riddled by noises.' Whether we are dealing with the human voice singing words - 'the pronunciation of most consonants produces irregular vibrations' - or the sound of an instrument like the violin - where the string produces both 'periodic' and 'non-periodic' vibrations - noise is an inescapable component on any tone. A truly pure sound 'can only be made in an acoustical laboratory, and even there it is doubtful whether, by the time the tone has reached our ear, it has not been corrupted by resonances picked up on the way' (Cowell, 2007: 23). Cowell suggests we get over the 'ill-repute' of noise and learn to embrace its aesthetic potential:

noise remains a much-used but almost unknown element ... perhaps owing to its ill-repute ... [But] a loud sound is literally noisier than a soft one ... [and] music does not touch our emotional depths if it does not rise to a dynamic climax ... the noise element has been to music as sex to humanity, essential to its existence, but impolite to mention ... Men like Varèse, in his Hyperprism and Arcana or Bartok, in his Piano Concerto ... render a service by opening a wide field for investigation. 
Modernity then, as Varèse (2007: 18) puts it, 'liberates' sound by introducing 'never-before-thought-of-use' for both the 'harmonic possibilities of the overtones' and the 'interferences created by the partials' or nonharmonic overtones. He describes this discovery as the 'entirely new magic of sound!' (Varèse, 2007: 18).

The 'never-before-thought-of' aspect of modern life requires what the sociologist of cognitive styles, Eviatar Zerubavel (1991), terms a 'fuzzy mind.' The 'fuzzy mind' is incapable of thinking analytically or of perceiving reality as a discrete set of disconnected entities. Zerubavel (1991: 82) suggests that children tend to epitomize the cognitive style in question to the extent that they have problems 'thinking in a "focused" manner'; separating the 'relevant from the irrelevant'; and don't 'seem to appreciate conventional closure, spatial or temporal.' Something like the fluid thought of children can be found in mythical thought, which blends 'dreams and symbols' with the "real" world'; and also in art, which is a 'stylized form of fantasy. A mental type of adventure ... [which] respects no boundary' (Zerubavel, 1991: 83; 96). Zerubavel (1991: 106) proposes that 'attitudes towards ambiguity vary even within the same culture across time' and that the 'fuzzy mind' has achieved a certain 'cultural prominence since the late nineteenth century.' He adds that the 'modern bent for fluidity' is perhaps most manifested in the arts where spatio-temporal boundaries are constantly blurred in 'poems that begin in the middle of a word with parentheses ... musical pieces that end before the final resolution of the tonic, and theatrical performances that continue throughout the intermission' (Zerubavel, 1991: 107-8).

The notion that fluidity and ambiguity might be a positive is explored in Richard Sennett's (1970) The Uses of Disorder. As an urbanologist, the author recognizes that a modern cultural form like the city can appear faceless and lacking in community, crowded and somewhat claustrophobic. It can also appear overly planned and built on an inhumane scale. But, argues Sennett (1970: xvii), 'the jungle of the city, its vastness and loneliness, has a positive human value. Indeed, I think certain kinds of disorder need to be increased in city life, so that men can pass into full adulthood.' Not for nothing has the city been such a central site of modern artistic experimentation. The chaos has generated creativity; and, in the words of Raymond Williams (2007), allowed artists to realize that aesthetic codes are to some extent 'constructed' and therefore re-constructible.

However, this raises something of a dilemma for people living in modernity: namely, what balance to strike between order and disorder? And, to what extent is the balancing act between order and disorder amenable to rational control? In her perceptive analysis of cultural change in modernity, Bernice Martin (1981: 84) makes the point that the equation of art with 'techniques for achieving the expression or transcendence' through disorder is uniquely modern. In modernity, disorder and creativity became conjoined in the idea of 'permanent change' in artistic styles. Traditional rules and 


\section{Twentieth Century Music}

shared symbolic codes were rejected once art became a separate sphere of activity, with its own 'sacred values.' In short, it is the art of the modern period, which expresses a 'preference for the transcendent over the finite, for taboo breaking over convention, for innovation over repetition' (Martin, 1981: 86).

Martin makes two further suggestions regarding the condition of art in modernity that are very useful for the present project. The first is that behind the many 'isms' in the modern arts lies 'the family face of Romanticism' (Martin, 1981: 84). The ethos of nonconformity that we find in Modernism dates from Romanticism and clearly did not exist before the advent of modernity:

In medieval Europe the artist was a craftsman/artisan or, if he worked with words or music, a cleric ... By the 18th century he may have been a gentleman ... In any case ... [the] artist himself might be a conformist or troublemaker in his personal capacity but no special éclat attached to nonconformity. Gesualdo was a murderer and Purcell is said to have died of a chill caught when his wife locked him out after one of the many nights out on the town ... but Bach lived a model and orderly domestic and civic life ... The idea that the true artist is a rebel and a sufferer or that insanity and wildness are inseparable from genius is a myth of Romanticism.

(Martin, 1981: 85)

It is necessary to take the Romantic mythology regarding the arts into consideration because, in many respects, it is what has led to the various aesthetic and communicative dead-ends experienced in modernity. Martin (1981: 12) describes its consequences on aesthetic communication thus: 'by eliminating the saving, Classical negation ... [the Romantic impulse] releases the terrors and the ennui of ultimate meaninglessness.' We will see that, in the case of twentieth century music, many composers had to struggle with the knowledge that 'Without definitions, boundaries and margins, we are incapable of apprehending even the possibility of the infinite, of selftranscendence' (Martin, 1981: 12).

The second significant contribution that Martin's analysis of cultural change makes to a theory of modernity lies in her suggestion that the modern artistic elite have often functioned like members of a religious clerisy or sect. Martin borrows the concept of 'myths of the elite,' from the mythologist Mircea Eliade (1964), to discuss the character of the modern avant-garde:

The 'difficulty' of much modern music, art, literature (and, indeed, its apparent 'meaninglessness') ... [can be likened] to the initiatory ordeals of archaic and traditional societies. One's 'understanding' of such 
difficult works sets one apart from the uninitiated mass and proclaims membership of an elite gnosis.

(Martin, 1981: 42-43)

This is not meant to imply that all modern art, architecture or composition was difficult in the same way. There were multiple 'sects' in existence within each field. In architecture, there were those, like Gaudi and the art noveau, who championed the curve and ornamentation over the straight line and functionality; in music, a healthy number of composers continued to compose tonal or neo-Romantic music. But what Martin is trying to get at is that 'esoteric' and 'difficult' came to be seen as valuable aesthetic and moral properties; they became central features of the Modernist myth of creativity and artistic renewal.

Martin is not alone in seeing the cultivation of difficulty as a quasi-religious attitude, which frames art as a type of spiritual leadership. (NB: As we shall see in Chapters 7-10, the claims to spiritual leadership assumed, in the case of the twentieth century composer, four prominent types: the prophet, priest, ascetic and mystic). In From the Baubaus to our House, Thomas Wolfe (1981) contends that by rejecting human and transcendental ideals, modern art and architecture retreated into esoteric codes and practices. He labels this retreat into esotericism as the 'compound' mentality:

It was the compounds that produced the sort of avant-gardism that makes up so much of the history of 20th century art. The compounds whether the Cubists, Fauvists, Futurists, or Secessionists - had a natural tendency to be esoteric, to generate theories and forms that would baffle the bourgeoisie. The most perfect device, they soon discovered, was painting, composing, designing, in code ... Composers, artists, or architects in a compound began to have the instincts of the medieval clergy, much of whose activity was devoted exclusively to separating itself from the mob. For mob, substitute bourgeoisie - and here you have the spirit of avant-gardism in the twentieth century.

(Wolfe, 1981: 19)

Much of the task of selling the esoteric and the difficult fell to theorists and the authors of manifestos. Wolfe (1981: 19; 121) quips that there 'were no manifestos in the world of art prior to the twentieth century' and that, for any 'ambitious architect, having a theory became as vital as having a telephone.' Martin (1981: 84) adds that, in the modern arts, making art has often been little more than an 'excuse for an essentially cerebral meditation' and that artistic practitioners have, for most of the century, been 'both haunted and fascinated' by the intellectual 'isms' coming out of 'academic circles' (e.g., Marxism, structuralism, semiotics, and deconstruction). Modern art has highlighted that nihilism and intellectualism can work in tandem - and often have in modernity. 
The 'compound mentality,' as Wolfe describes it, was particularly acute in the case of music. He says of the twentieth century composer who, he says, had all the 'instincts of the medieval clergy' (Wolfe, 1981: 19):

In the field of serious music, the case was ... very nearly terminal. Within the university compounds, composers had become so ultraSchoenbergian, so exquisitely abstract, that no one from the outside world any longer had the slightest interest in, much less comprehension of, what was going on ... not even that Gideon's army known as the "concert-going public" could be drawn to an all-contemporary program. They took place only in university concert halls ... The same thirty-five or forty souls, all of them faculty members and graduate students, make up the audience at every contemporary musical event.

(Wolfe, 1981: 89).

Does the 'terminal' state almost reached by classical composition really matter? Is this not a storm in an avant-garde teacup? As I will argue in Chapters 11 and 12, with respect to the demise of the avant-garde and the likelihood of musical re-enchantment, it matters because music has - rightly or wrongly - been conceived as an art that expresses something about the spiritual condition of modernity. The philosopher of history, Oswald Spengler (1954: 315), was amongst the first to comment on how 'After the Renaissance the notion of God sheds the old sensuous and personal traits (omnipresence and omnipotence are almost mathematical concepts), becomes little by little identical with the notion of infinite space and in becoming so becomes transcendent world-will.' It is therefore around 1700 'that painting has to yield to instrumental music - the only art that in the end is capable of clearly expressing what we feel about God' (Spengler, 1954: 315). But, by the time the German author Thomas Mann (1949: 231, penned the twentieth century novel Doctor Faustus, based on the life of a fictional Modernist composer, the metaphysical and aesthetic power of music was deemed to belong to the Devil: 'the true master and giver of such rapture.' For the Adrian Leverkühn, the fictional composer, as for Adorno who was philosophical and musicological counselor to Mann during the writing of Doctor Faustus - the only role music could play in the modern world was that of 'representation of universal self-alienation' (Etter, 2001: 2). The inability of modern music to function as affirmative transcendence led Jean-Francois Lyotard (1974) to label modern music a kind of 'negative theology' (see de la Fuente, 1999).

This is yet another irony in the entanglement of music and modernity the will-to-purification (i.e., instrumental music based on tonal principles) rebounded into a form of re-enchantment (i.e., music as a spiritual and transcendental art) only to become, in the twentieth century, a reminder of the impossibility of transcendence. This state of affairs becomes an issue because of the perceived 'distance' between music and society in the last 
century; or - as we shall see in Chapter 6 - because of the 'communication gap' between composers and audiences. The difficulties faced by the modern composer stem from a fundamental paradox: as an 'alogogenic, completely unrelated to language, non-artifact, having no physical existence' music courts the possibility of becoming 'a self-referential, aural abstraction' (Born, 1991: 166). This tendency is exacerbated in modern societies by virtue of 'the high development of role-specific knowledge [that] allows music to be removed to a considerable distance from the central core of everyday life' (Shepherd, 1976: 14). As Michael Chanan (1994: 4) puts it, while 'Western civilization proclaims its music as one of its proudest achievements,' it is also true that the 'Western system of notation has allowed' music to be divided 'into two separate processes: composition ... and performance.' In the case of so-called 'serious' or art music, 'it's almost as impossible for someone with no formal education in music to read a piece of musical analysis as it is for someone who is not a chemist to read a research paper in chemistry' (Chanan, 1994: 6).

We have highlighted some of the cultural and existential dilemmas facing the twentieth century composer. He or she has been caught between the competing demands of originality and communicability, the need to break codes and the need to provide listeners with sufficient cues to follow and appreciate a piece of music. For composer George Rochberg (1984: 334), the competing demands are heightened by the fact that music is a temporal art: 'Because music is precisely a temporal art, it loses meaning in exact ratio to the degree of “forgetting” built into it' (Rochberg, 1984: 334). Without the ordering principles of tonality, much 'of what still goes under the name of “music”,' claims Rochberg (1984: 332), is 'either simply sound-generation or soul-less complexity or mindless minimalism.' The conclusion is that Modernism became 'insensitive to the hungers of the human spirit' and the arts lost their 'power 'to interest or move listeners, viewers, readers' (Rochberg, 1984: 331). Whether or not this was inevitable, will be a central question for this book.

A few preliminary remarks are in order regarding the empirical scope of the book. By 'twentieth century music,' this study means the art or classical music of the last century. The contours of this musical culture run from figures such as Debussy, Schoenberg, Stravinsky, Les Six, Charles Ives and Henry Cowell to composers such as Philip Glass, Steve Reich, John Adams and Brian Ferneyhough. In between these two end points, the musical culture produced charismatic figures such as Olivier Messiaen, Pierre Boulez, Karlheinz Stockhausen, John Cage, Morton Feldman, Gyorgy Ligeti and Luciano Berio. Underpinning the list of names is a range of styles and musical innovations: atonality; primitivism; Neo-Classicism; twelve-tone music; total serialism; aleatoric techniques; electronic music; minimalism; postmodern 'collage'; and the 'New Complexity.' Morgan (1984: 458) posits that the 'most important historical moment in defining the main coordinates of twentieth century music was the widespread break from traditional 


\section{Twentieth Century Music}

tonality that occurred during the first decade of the century.' It was this that gave rise to the 'expressive variety' and 'linguistic plurality' of the 'modern age' (Morgan, 1984: 458).

The label 'twentieth century' is arguably less polemical than 'contemporary,' 'modern' or 'new.' The latter seem more suited to rallying the troops. Thus, we have the International Society for Contemporary Music (established in 1922); journals such as Modern Music (established in 1924); and, the more academic, Perspectives of New Music (established in 1962). Interestingly, the term 'twentieth century music' has survived both the end of the century and the death of the various musical 'isms' associated with the last century.

However, it should be acknowledged that the label has generated criticism from scholars associated with the 'new musicology.' For example, Derek B. Scott (1990: 385) expresses annoyance at the fact that 'Jimi Hendrix is not in the New Grove' and that 'if you look for Charlie Parker in the New Oxford History of Music, you find Horatio Parker instead.' Equally critical is Susan McClary's (1989), 'Terminal Prestige: The Case of Avant-Garde Composition,' which argues: 'Perhaps only with the twentieth century avant-garde ... has there been a music that has sought to secure prestige precisely by claiming to renounce all possible social functions and values' (McClary, 1989: 60). My own position in this book is that, as a cultural sociologist, I should study how labels are used and the kind of symbolic work they perform. In any case, symbolic associations are not exhausted by the intentions of the composer or, for that matter, performer. Arved Ashby (2004a: 2) argues that it is equally important to map the meanings that even twentieth century music has 'held for a significant number of listeners' and that this may require going well beyond the confines of 'art musical institutions' (for e.g., the role of modernist music in film soundtracks). As we shall see in Chapter 11, there are those historical moments when a twentieth century composer and his or her music have resonated with the culture more broadly - for example, the music of Stockhausen in the 1960s.

One of the exciting things about undertaking a project that aims to bring social theory and music history together is that the dialogue between the two disciplines is expanding all the time. These days, social science perspectives seem to be taken more seriously by music scholars. Thus, Clarke and Cook (2004: 5) propose a 'musicology that embodies a principled awareness of both the potential to engage with large bodies of relevant data, and the appropriate methods for achieving this'; and the sociologist Tia DeNora (2004: 38-39), a contributor to Clarke and Cooke's volume, suggests that the 'sociology of music has found its empirical feet and thus a way to ground its claims about the links between music and society.' In this respect, it is interesting that two major sociological studies of twentieth century music, Georgina Born's (1995) Rationalizing Culture (a study of Boulez and IRCAM) and Catherine Cameron's (1996) Dialectics in the Arts (a study of American experimental music), were both conducted by 
anthropologists, thereby producing highly contextualized and empirically rich accounts of those musical cultures.

However, the present book is operating within a different genre of sociological analysis: namely, the kind of theoretical framework associated with cultural sociology. While cultural sociology is no easy thing to define in particular, after the plethora of approaches unleashed by the so-called 'cultural turn' - Jeffrey C. Alexander's (2003: 3-4) programmatic book The Meanings of Social Life proposes that a cultural sociology examines the 'unconscious cultural structures that regulate society.' Its goal is therefore similar to that of psychoanalysis and the study of mythology in bringing to light the 'social conscious' and revealing to 'men and women the myths' that they draw upon to make sense of the world (Alexander, 2003: 4). Such a cultural sociology is pitted against the sociology of culture (and its sub-divisions such as the sociology of art, knowledge and religion), for it sees the latter as unconcerned 'with interpreting collective meanings, much less with tracing the moral textures and delicate emotional pathways by which individuals and groups come to be influenced by them' (Alexander, 2003: 5).

Other authors have argued that a Kultursoziologie of modernity is evident already in 'theorists like de Tocqueville and Durkheim, Weber, Simmel and Mannheim' (Zijderveld, 1982: 9). The work of these classical theorists doesn't constitute a single theoretical system but it does point to a joint interest in the social meaning of customs and manners, collective representations, art forms, life experiences, religious worldviews and the effects of urbanization and rationalization on culture. Roland Robertson (1978: 5) proposes sociologists interested in a 'cultural foci' return to classical theorists like Weber and Simmel. He also defines cultural sociology as a style of analysis:

Cultural sociology is not a school or a particular theoretic tendency. Rather it is a style of analysis - a standpoint which insists on the salience of concern with life as well as society, concern with the role of ideas and symbols and the transmission of historicity, and a number of other matters which are best exposed by ways of detailed case-studies.

(Robertson, 1978: 7)

Robertson (1978: 6) admits that "Cultural sociologists are still charged with being too "humanistic", too "philosophical" or whatever.' While the passage of time has seen a greater acceptance of cultural approaches, there is still some truth in the claim that not all social scientists are willing to accept that the 'soft variables' of art, symbols and culture are as important as the 'hard variables' of power, social structure and material conditions (on this debate see Rojek and Turner, 2000). However, there is a danger that in their concern with 'hard variables' sociologists leave discussion of artistic modernity to humanists; or that they fail to explore the symbolic responses of 
artists to modernity. As Martin (1982: 2) suggests, 'art forms are part of the modern culture's reflection' upon the principle of Romanticism and a sociologist studying modernity encounters a topic 'already well worked by artists, philosophers, scientists and folk bricoleurs.' Even an arch-Modernist' like Schoenberg would claim:

It has always been my belief that a composer speaking of his own problems speaks at once of the problems of mankind. But he does so in a symbolical way ... expressing matters of philosophy, economy or problems of labor, society or morals.

(Cited in Harvey, 1999: 52)

What has been discernible in recent socio-cultural discussions of modernity is an increasing recognition that revolutionary changes in ways of 'seeing,' 'hearing' and 'writing' the world were just as central to the phenomenon of modernity as the application of reason and intellect. David Harvey (1989: 216) offers one such theoretical perspective when he writes: 'Modernization entails ... the perpetual disruption of temporal and spatial rhythms, and Modernism takes as one of its missions the productions of new meanings for space and time in a world of ephemerality and fragmentation.' In Art and Social Structure, Robert Witkin (1995) welcomes such attempts to overcome the puzzling lag in social theory appropriating aesthetic discussions of modernity:

The theorizing concerning modernity has some puzzling lacunae in it. The critical reflections of ... [recent] thinkers on modernity constitute a project that echoes many of the concerns and ideas of modernist artists in the early years of the [twentieth] century. Why were these artists so modern? Why did academic culture take so long to catch up? Should not this cultural lag be itself an important topic of theorizing?

(Witkin, 1995: 31)

In some respects, it was cultural historians - many of whom will be drawn upon in this study - who were first to highlight the consequences of artistic Modernism for a discussion of modernity. This book will be reliant on such cultural histories. Such studies tap into the symbolic and mythological quality of artistic Modernism; as well as the agency that the arts exercised upon the world. To quote from Modris Eksteins (1989: xvi), who uses Stravinsky's Rite of Spring as a symbol of twentieth century modernity - including the destructive qualities of that modernity - art ought to be 'regarded as a social phenomenon and Modernism as the principal urge of our time.' The study of 'principal urges' is something that a cultural sociology of modernity, from Weber onwards, has been committed to exploring. In this, and various other respects, the cultural history and cultural sociology of modernity converge. 
Admittedly, examining modernity through its music is no easy task. But, such an undertaking is possible. Musical sounds have symbolic connotations that, while possessing a degree of referential 'openness,' point towards wider aspects of the culture. Thus, Ben Arnold (1991: 19) argues in relationship to the link between war and music in modernity, 'that even without text or descriptive titles,' music has had the ability to create the 'impressions of war.' How does music do this? Arnold (1991: 19) suggests that, since the public expects the sounds of war to include 'bombs exploding or whistling through the air, guns firing, airplane engines roaring, sirens blaring and humans screaming,' it has been possible to encode these sound associations through different orchestral techniques and instruments. Tone clusters, glissandi and the abrupt introduction of brass or timpani have all been used to provide the listener with the experience of war and violence more generally. Indeed, the music can evoke such emotional and psychic states more successfully than words or images. Arnold (1991: 20) writes: 'When the title Threnody to the Victims of Hiroshima is read or spoken, the listeners do not have the same reaction as they do when they hear the work.' It goes without saying that Krystof Penderecki's score could only have been composed in the twentieth century; and, even though music is not a mimetic art form, Threnody to the Victims of Hiroshima speaks to the last century and to the experiences it wrought.

To summarize: in approaching the question of modernity via the culture and practices of twentieth century musical culture, the present book could be seen as a case study in the social theory of modernity. The book will explore what twentieth century musical culture tells us about the condition of being modern and living a modern existence. This is not meant to imply that the twentieth century musician was some kind of heroic figure that was uniquely aware of the conflicts and contradictions associated with living in modernity. However, even a high-minded populist who self-consciously avoids giving too much attention to so-called 'high culture' would have to admit that cultural specialists are an interesting if annoying species of human beings and worthy of study. Arguably, the very existence of musicians devoted to such a specialized activity, in an age of democracy and populism, is itself a puzzling cultural curiosity. In short, the twentieth century composer and his or her arcane, highly specialized art promises to tell us a great deal about the hopes and frustrations, aspirations and limitations, of living a modern existence. If this book contributes, through its case study, to an applied socio-cultural theory of modernity, it will have achieved its aims. 